E.M. Demianenko, A.G. Grebenyuk, V.V. Lobanov, V.A. Tertykh, I.S. Protsak, Yu.M. Bolbukh, R.B. Kozakevych

\title{
QUANTUM CHEMICAL STUDY ON INTERACTION OF DIMETHYL CARBONATE WITH POLYDIMETHYLSILOXANE
}

\author{
Chuiko Institute of Surface Chemistry of National Academy of Sciences of Ukraine \\ 17 General Naumov Str., Kyiv, 03164, Ukraine, E-mail: Demianenko_en@mail.ru
}

\begin{abstract}
Possible mechanisms of interaction of dimethyl carbonate with polydimethylsiloxane have been examined by density functional theory method with exchange-correlation functional B3LYP and basis set 6-31G $(d, p)$. A carbon atom attack of the carbonyl group of dimethyl carbonate molecule at the oxygen atom of the siloxane bridge of polydimethylsiloxane with simultanious ester oxygen atom attack of dimethyl carbonate at the silicon atom of organosilicon polymer have been found to be the most probable.
\end{abstract}

Keywords: dimethyl carbonate, polydimethylsiloxane, reaction mechanism, density functional theory method, cluster approach

\section{INTRODUCTION}

Nowadays there are more than one hundred of brand names of pyrogenic silica with grafted organic groups (first of all methylsilicas) on the world market. Nevertheless, there is a limited number of the products with content of organic groups of more than $3 \mathrm{wt}$. \% (by carbon) whereas a lot of directions of potential applications need modified high disperse materials with carbon content of up to $6 \mathrm{wt}$. \%. This is connected with difficulties of developing reproductible methods of synthesis for chemically modified disperse silicas with great content of grafted organic groups because of a necessity to use low-volatile oligomeric organosiloxanes as surface modifying reagents. Usually in such cases variuos kinds of polydimethylsiloxanes (PDMS) are used with different molecular masses and viscosities. Difficulties in application of organosiloxane oligomers to chemical modification of high disperse silicas are caused by low reactivities of these compounds with respect to surface active sites $[1,2]$. One of peculiarities of organopolysiloxane molecules is their capability to form a helicoidal structure due to probability of a substituent (methyl groups in case of polydimethylsiloxanes) rotation around $\mathrm{Si}-\mathrm{O}$ bonds. This restricts the number of segments capable to interact with silica surface sites. One of the probable ways to increase the reactivity of an organosilicon polymer is depolymerization of high molecular polydimethylsiloxanes followed by grafting oligomers formed on the surface of silica particles. Depolymerization can be realized by heat treating or in the presence of such reagents as alkalies, sulfuric and hydrochloric acids, or amines [1-3]. A special attention is drawn by use of socalled "green" reagents, in particular dimethyl carbonate (DMC) or diethyl carbonate, for depolymerization of organosilicon polymers $[4,5]$.

It is known from the experiment $[6,7]$ that due to interaction between dimethyl carbonate and polydimethylsiloxane a reaction product is formed with viscosity considerably lesser than those of parent substances, so a conclusion can be made on the rupture of chemical bonds in polydimethylsiloxane chains. Authors paper [5] examined depolymerizasion of polysiloxanes with dimethyl carbonate solution in methanol with addition of alkali metal halogenides as catalysts. According to the results of analysis, final reaction products formed due to interaction between polydimethylsiloxane and dimethyl carbonate in such a system are carbon dioxide, dimethyldimethoxysilane, and trimethylmethoxysilane:

$$
\begin{aligned}
& \left(\mathrm{CH}_{3}\right)_{3} \mathrm{Si}-\left[\mathrm{OSi}\left(\mathrm{CH}_{3}\right)_{2}\right]_{n}-\mathrm{CH}_{3}+n\left(\mathrm{CH}_{3} \mathrm{O}\right)_{2} \mathrm{CO} \rightarrow \\
\rightarrow & (n-1)\left(\mathrm{CH}_{3}\right)_{2} \mathrm{Si}\left(\mathrm{OCH}_{3}\right)_{2}+2\left(\mathrm{CH}_{3}\right)_{3} \mathrm{SiOCH}_{3}+n \mathrm{CO}_{2}
\end{aligned}
$$

Dimethyl carbonate is ambident electrophilic reagent containing both relatively hard electrophiles (carbon in $\mathrm{C}=\mathrm{O}$ groups) and soft electrophiles (methoxy carbon atoms). When attacking a hard electrophile, carboxymethylation of nucleophilic reagent occurs, and during 
interaction with soft electrophile - the process of methylation takes place $[8,9]$. The interaction between polydimethylsiloxane and dimethyl carbonate results in the siloxane bond rupture, but the mechanism of this process is not yet clear enough. In order to recognize probable reaction mechanisms, use of quantum chemical methods is reasonable within cluster approach that give an opportunity to examine a number of alternative mechanisms of chemical reactions and to ascertain the most probable one.

The aim of this work is elucidation of the probable mechanism of interaction between dimethyl carbonate (DMC) and polydimethylsiloxane (PDMS) by means of computer simulation. It is necessary to localize complexes of initial substances and of reaction products as well as respective complexes of the transition states for probable reaction mechanisms.

\section{METHOD}

All the calculations have been carried out by the help of program US GAMESS [10] by density functional theory method with exchangecorrelation functional B3LYP [11, 12] and basis set 6-31G $(d, p)$.

The value of activation energy was found by a formula:

\section{$\Delta E_{\text {act }}=E_{Z P E}$ (transition state) $-E_{Z P E}$ (reactants)}

and the free energy effect of the reaction $\left(\Delta G_{\text {реакі }}\right)$ by:

$\Delta E_{\text {react }}=E_{Z P E}$ (reaction products) $-E_{Z P E}$ (reactants),

where $E_{Z P E}=E_{t o t}+\mathrm{ZPE}$ and $E_{\text {tot }}-$ total energy of respective optimized structure whereas zero-point energy (ZPE) was evaluated due to calculation of the Hesse matrix for every state.

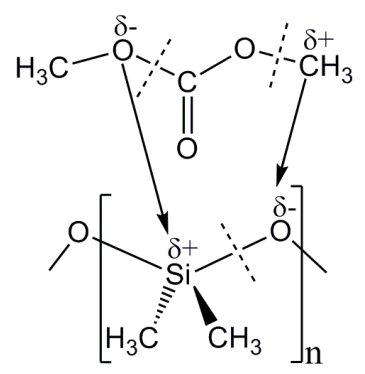

$a$

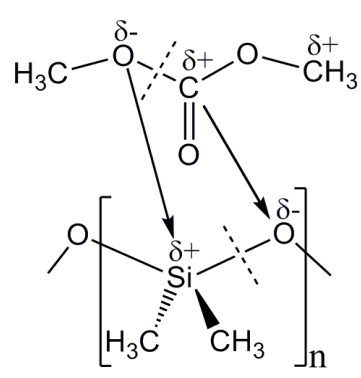

$b$
The equilibrium spatial structures of the molecules of reactants and reaction products as well as configurations of transition states were found by gradient norm minimization. The stationarity of the energy minima for relative structures was proved by the absence of negavive eigenvalues of the Hess matrices (matrices of force constants) whereas the presence of transition states was confirmed by existence of transition vectors (iv) according to the Murrell-Laidler theorem [13]. A correspondence between the structures of initial substances, transition states, and reaction products was secured by use of IRC method [14].

\section{RESULTS AND DISCUSSION}

Only mechanisms of interactions between DMC and PDMS have been examined resulted in shortening polymeric chain of PDMS. Taking into account the effective net charges on the atoms of DMC and PDMS molecules, following schemes of their interaction mechanisms can be proposed (Fig. 1). In particular, the carbon atom of methyl group of DMC molecule can attack the oxygen atom of siloxane bridge of PDMS molecule whereas the oxygen atom situated near another methyl group of DMC molecule can interact with the silicon atom of PDMS molecule resulting in the rupture of $\mathrm{C}-\mathrm{O}$ bond between methyl group and esteric oxygen atom of DMC molecule simultaneously with rupture of $\mathrm{Si}-\mathrm{O}$ bond of siloxane bridge, so decreasing the length of PDMS polymeric chain (Fig. 1 a).

According to the second route, the carbon atom of carbonyl group of DMC molecule coordinates the oxygen atom of siloxane bond of PDMS molecule whereas the esteric oxygen atom of DMC molecule attacks the silicon atom of PDMS molecule (Fig. $1 b$ ).
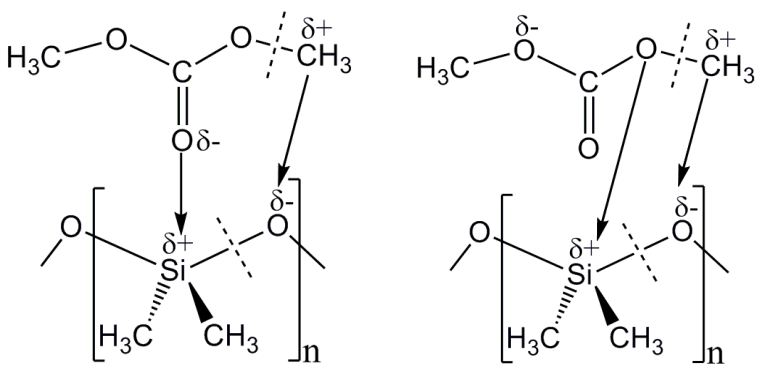

Fig. 1. Directions of the probable attack of dimethyl carbonate molecule interacting with a fragment of polydimethylsiloxane chain (see text) 
Within the third probable route, the carbon atom of methyl group of DMC molecule attacks the oxygen atom of siloxane bond of PDMS molecule whereas the oxygen atom of carbonyl group of DMC molecule interacts with the silicon atom of PDMS molecule (Fig. $1 c$ ).

The fourth route considered consists in the attack of the carbon atom of methyl group of DMC molecule on the oxygen atom of siloxane bridge of PDMS molecule whereas the adjacent esteric oxygen atom of DMC molecule attacks on the silicon atom of PDMS molecule (Fig. $1 d$ ).

The first route. When considering the first route, in order to take size effect into account, a PDMS models were used with various number of $-\mathrm{OSi}\left(\mathrm{CH}_{3}\right)_{2}-$ units (from 2 to 7 ).

This mechanism appeared to be one-stage reaction (Fig. 2 a), i.e. due to interaction between reactants simultaneously three existing bonds are ruptured and two new covalent bonds are formed resulting in separation of carbon dioxide molecule and of two PDMS links of smaller size. A cyclic six-membered transition state (Fig. 2) is a characteristic of this route, nevertheless the activation energy value appeared to be unexpectedly high (about $450 \mathrm{~kJ} / \mathrm{mol}$, see Table 1) and the energy effect of this reaction is positive (about $60 \mathrm{~J} / \mathrm{mol}$ ) what testifies a small probability of the process from the thermodynamic point of view. It is seen from Fig. $2 b-g$, that the structure of transition state is almost the same independently on number of links in the PDMS model.

An analysis of the results of calculations of kinetic and thermodynamic parameters testifies (Table 1) that if the number of links in PDMS increases from 2 to 7 , the activation energy value for this mechanism decreases for $23 \mathrm{~kJ} / \mathrm{mol}$ whereas the energy effect of the reaction decreases only for $0.3 \mathrm{~kJ} / \mathrm{mol}$.<smiles>COC(=O)OC</smiles>

IR

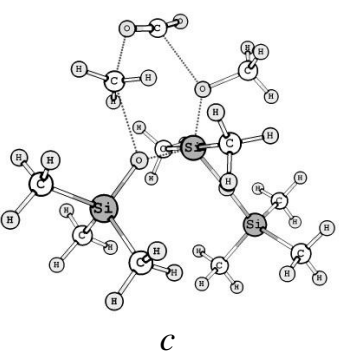<smiles>CO[Si](C)(C)O[Si](C)(C)[C@@]1(C)OCOC(=O)O1</smiles>

TS

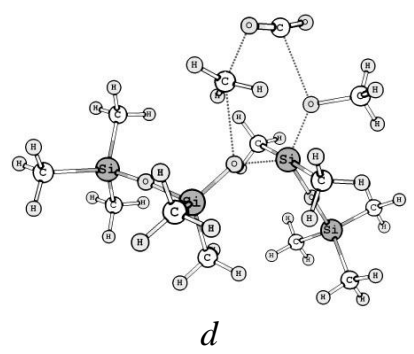

$\mathrm{o}=\mathrm{c}=\mathrm{O}$<smiles>CO[Si](C)(C)C</smiles>

RP

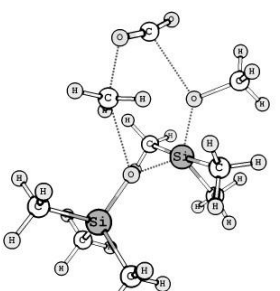

b

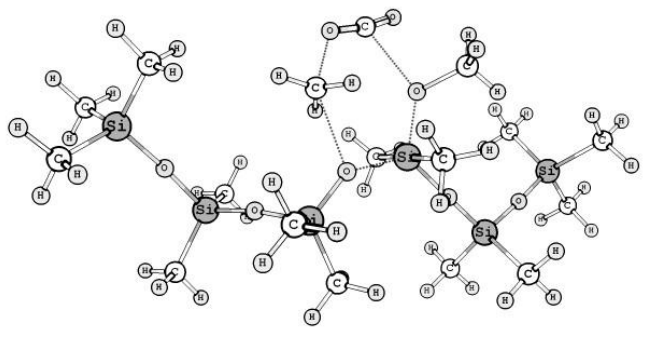

$f$

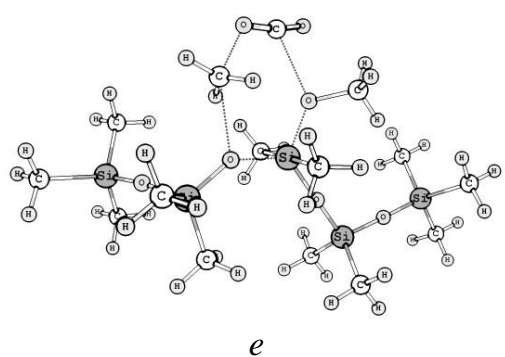

$e$

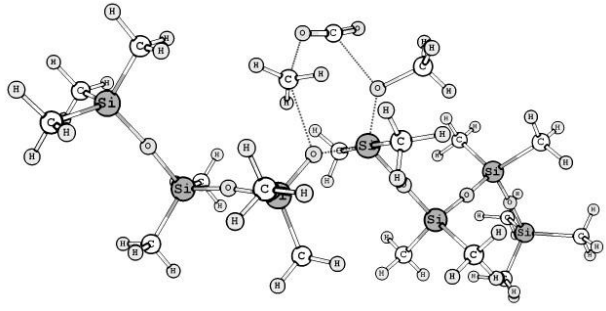

$g$

Fig. 2. Equilibrium structure of the transition states of interaction between DMC and PDMS according to the first route (a) with different number of links - $\mathrm{OSi}\left(\mathrm{CH}_{3}\right)_{2}-$ from 2 to $7(b-g)$, here and later: IR - initial reagents, IM - intermediate, $\mathrm{TS}$ - transition state, $\mathrm{RP}$ - reaction products 
Table 1. The values of activation energy and of energy effect for inreaction between DMC and PDMS according to the first route as dependent on the number of links in PDMS

\begin{tabular}{ccc}
\hline $\begin{array}{c}\text { Number of links } \\
-\mathbf{O S i}\left(\mathbf{C H}_{\mathbf{3}}\right)_{2}-\end{array}$ & $\begin{array}{c}\boldsymbol{\Delta} \boldsymbol{E}_{\text {act }}, \\
\mathbf{k J} / \mathbf{m o l}\end{array}$ & $\begin{array}{c}\boldsymbol{\Delta} \boldsymbol{E}_{\text {react }}, \\
\mathbf{k J} / \mathbf{m o l}\end{array}$ \\
\hline 2 & 475.6 & 60.1 \\
3 & 463.8 & 59.4 \\
4 & 456.0 & 58.6 \\
5 & 453.9 & 57.4 \\
6 & 453.0 & 59.2 \\
7 & 452.6 & 59.8 \\
\hline
\end{tabular}

As it is seen from the plots (Fig. 3), further increase in the number of links for the PDMS model keeps these two values practically unaltered.

That is why a model of PDMS with two links was used in further calculations because increased number of links did not change noticeably the energetic parameters of the process.

The second route. The interaction between DMC and PDMS according to the scheme depicted in Fig. $1 b$ is described by a two-stage mechanism (Fig. 4). The first stage is a bimolecular reaction with 4-membered cyclic transition state TS1 and activation energy value of $264 \mathrm{~kJ} / \mathrm{mol}$ what is about one-half of the analogous value for the previous mechanism (see Table 2) whereas the energy effect of the reaction is equal to $44 \mathrm{~kJ} / \mathrm{mol}$ what is lesser than that for the previous route. The $\mathrm{Si}-\mathrm{O}$ bond rupture takes place and an intermediate (IM) is formed consisting of two products. One of them has an end silicon atom bound to methyl group via oxygen atom, the other has silicon atom bound to $-\mathrm{COOCH}_{3}$ group.

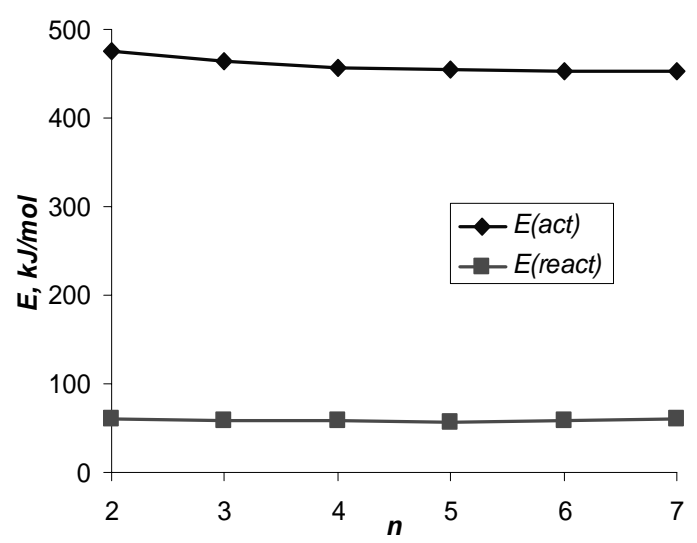

Fig. 3. Plots of the activation energy and of the energy effect for interaction between DMC and PDMS according to the first route as dependent on the number of links in PDMS

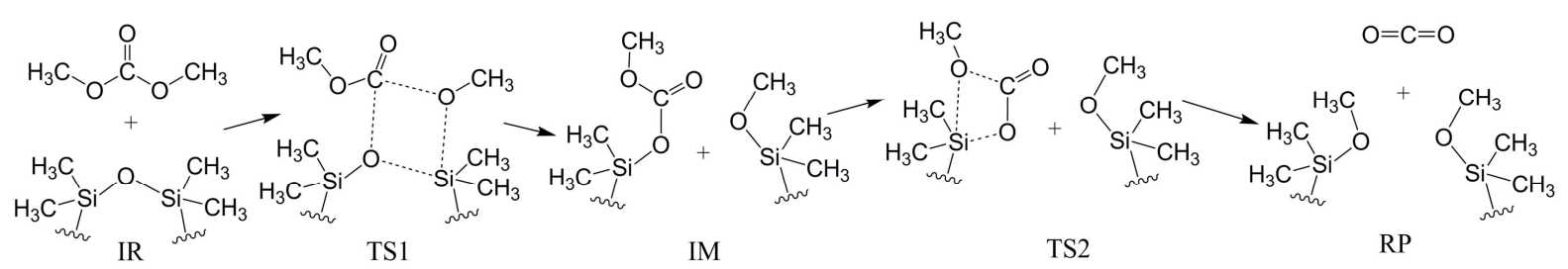
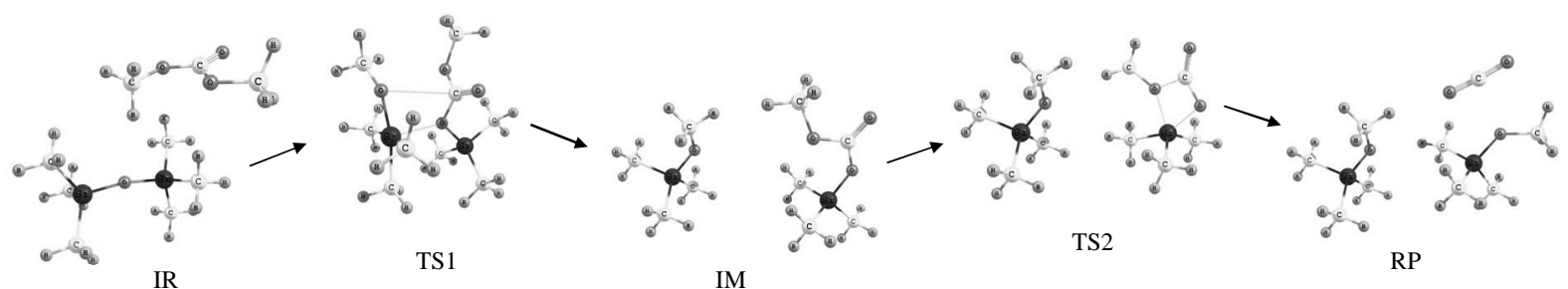

$b$

Fig. 4. Scheme of interaction $(a)$ between DMC and PDMS along with equilibrium geometries of molecular models $(b)$ according to the second route

The last surface compound can be subjected to monomolecular reaction of elimination with isolation of carbon dioxide molecule. This is just the second stage of this mechanism. The activated complex TS2 of that stage is also 4-membered (Fig. 4) where the oxygen atom of methoxy group is bound to silicon atom. Simultaneously, $\mathrm{Si}-\mathrm{O}$ and $\mathrm{C}-\mathrm{O}$ bonds are broken and carbon dioxide 
molecule is eliminated. The energy barrier overcome is for $130 \mathrm{~kJ} / \mathrm{mol}$ lesser than the activation energy value for previous reaction stage (complex TS1) and equals to $133.5 \mathrm{~kJ} / \mathrm{mol}$ whereas the energy effect is equal to $31.4 \mathrm{~kJ} / \mathrm{mol}$ (Table 2). This testifies the first stage of the mechanism to be limiting.

The third route. When simulating the interaction between DMC and PDMS in accordance with Fig. $1 c$, this route appears to be two-stage one similarly to previous mechanism. At the first stage, a 6-membered cyclic transition state TS1 (Fig. 5) is formed. When the molecular system overcomes the energy barrier of $341 \mathrm{~kJ} / \mathrm{mol}$, an intermediate is formed like that peculiar to the second route. The energy effect of this stage is rather close to that of the first stage of previous mechanism, despite different structures of transition states. Further transformation of this IM can be the same as in the previous mechanism or another one what will be considered later. Nevertheless, in any case, due to run of the second stage a carbon dioxide is eliminated and the stage itself is monomolecular. Thus, a 4-membered cyclic transition state TS2 (Fig. 5) can be formed where methyl group moves to the oxygen atom directly bound to silicon atom with simultaneous break of two $\mathrm{C}-\mathrm{O}$ bonds and isolation of $\mathrm{CO}_{2}$ molecule. The activation energy value for such a stage is equal to $311.5 \mathrm{~kJ} / \mathrm{mol}$, the energy effect of the reaction being equal to $22.4 \mathrm{~kJ} / \mathrm{mol}$. When comparing the values of activation energy for the second stages of the second and third routes, one can see that the second stage of the second route is more probable, as it is characterized by a lesser (for $178 \mathrm{~kJ} / \mathrm{mol}$ ) energy barrier.

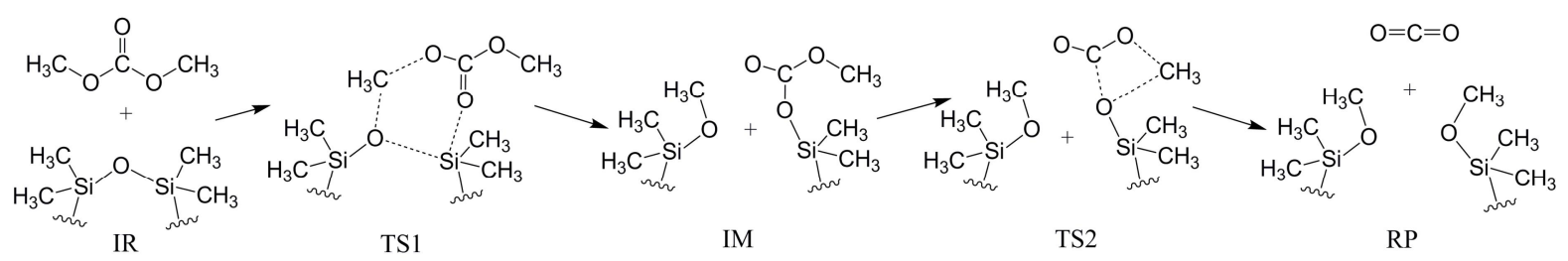

$a$

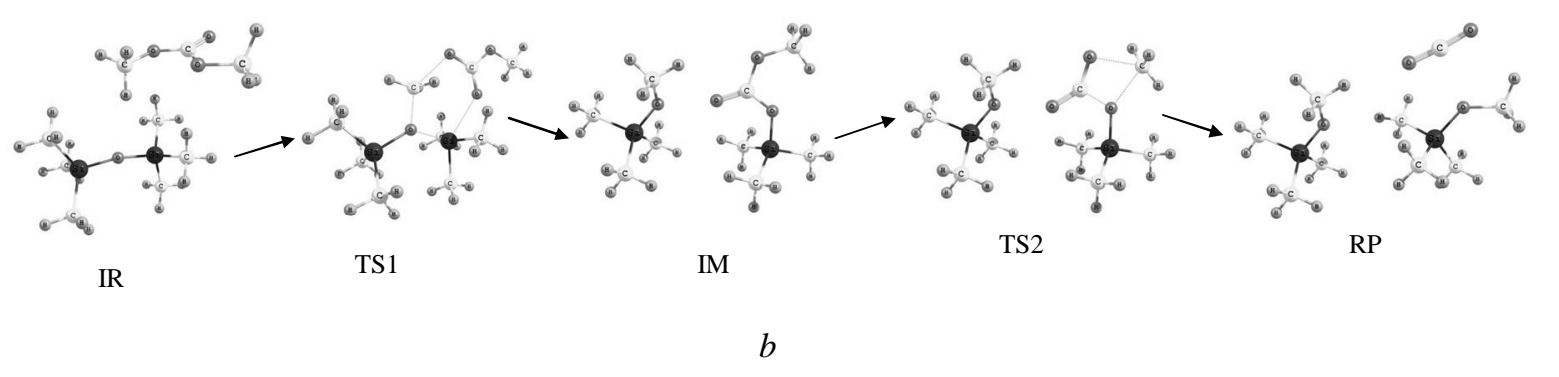

Fig. 5. Scheme of interaction $(a)$ between DMC and PDMS along with the equilibrium geometries of molecular models (b) according to the third route

Table 2. Energy parameters of three probable mechanisms of interaction between DMC and PDMS

\begin{tabular}{|c|c|c|c|}
\hline \multicolumn{2}{|c|}{ Pathways of reactions } & $\Delta E_{a c t}$ & $\Delta E_{\text {react }}$ \\
\hline \multicolumn{2}{|c|}{ pathway 1} & 475.6 & 60.1 \\
\hline \multirow{2}{*}{ pathway 2} & stage 1 & 264.3 & 43.8 \\
\hline & stage 2 & 133.5 & 31.4 \\
\hline \multirow{2}{*}{ pathway 3} & stage 1 & 341.0 & 43.5 \\
\hline & stage 2 & 311.5 & 22.4 \\
\hline
\end{tabular}

The fourth route. For the interaction mechanism depicted in Fig. $1 d$ we failed to localize the transition state, probably because of steric hindrances and critically small angle $\mathrm{C}-\mathrm{O}-\mathrm{C}$ in DMC respective to the interaction in this transition state.

When comparing the values calculated of the energy parameters of the first three routes (Table 2) 
for the PDMS model including two links $-\mathrm{OSi}\left(\mathrm{CH}_{3}\right)_{2}-$, one can approve that the second route is the most probable from both kinetic and thermodynamic point of view. In other words, the most probable is the mechanism where the carbon atom of carbonyl group of DMC molecule interacts with the oxygen atom of siloxane bridge of PDMS molecule whereas the esteric oxygen atom of DMC molecule attacks the silicon atom of PDMS molecule. As a result, a siloxane bond $\mathrm{Si}-\mathrm{O}$ in polymer is broken and carbon dioxide molecule is eliminated, the reaction running in two stages.

\section{CONCLUSION}

Our theoretical examination indicates that at interaction of polydimethylsiloxane with dimethyl carbonate the reaction route realized through formation of a complex with simultaneous participation of carbon atom of carbonyl group and oxygen atom of methoxy group of DMC is the most expedient.

\section{ACKNOWLEDGEMENT}

Calculations have been performed on the Computing System of Chuiko Institute of Surface Chemistry of National Academy of Sciences of Ukraine. The research leading to these results has received funding from the People Programme (Marie Curie Actions) of the European Union's Seventh Framework Programme FP7/2007-2013/ under REA grant agreement $\mathrm{No}^{\circ}$ PIRSES-GA2013-612484.

\title{
Квантовохімічне дослідження взаємодії диметилкарбонату з полідиметилсилоксаном
}

\author{
Є.М. Дем'яненко, А.Г. Гребенюк, В.В. Лобанов, В.А. Тьортих, \\ І.С. Процак, Р.Б. Козакевич, Ю.М. Больбух
}

Інститут хімії поверхні ім. О.О. Чуйка Національної академії наук України вул. Генерала Наумова, 17, Київ, 03164, Україна, Demianenko_en@mail.ru

\begin{abstract}
Методом теорії функиіоналу густини з обмінно-кореляційним функиіоналом В3LYP та базисним набором 6-3IG(d,p) досліджено можливі механізми взаємодї диметилкарбонату 3 полідиметилсилоксаном. Встановлено, щзо найбільш ймовірною $\epsilon$ атака атома вуглечю карбонільної групи молекули диметилкарбонату по атому кисню силоксанового містка полідиметилсилоксану з одночасною атакою естерного атома кисню диметилкарбонату по атому кремнію кремнійорганічного полімера.
\end{abstract}

Ключові слова: диметилкарбонат, полідиметилсилоксан, механізм реакиї, метод теорії функиіоналу густини, кластерне наближення

\section{Квантовохимическое исследование взаимодействия диметилкарбоната с полидиметилсилоксаном}

\author{
Е.Н. Демяненко, А.Г. Гребенюк, В.В. Лобанов, В.А. Тертых, \\ И.С. Процак, Р.Б. Козакевич, Ю.Н. Больбух
}

Институт химии поверхности им. А.А. Чуйко Национальной академии наук Украинь ул. Генерала Наумова, 17, Киев, 03164, Украина, Demianenko_en@mail.ru

Методом теории функиионала плотности с обменно-корреляционным функиионалом B3LYP и базиснылм набором 6-31G(d,p) исследовань возможные механизмы взаємодействия 
диметилкарбоната с полидиметилсилоксаном. Установлено, что наиболее вероятна атака атома углерода карбонильной группы молекуль диметилкарбоната по атому кислорода силоксанового мостика полидиметилсилоксана $c$ одновременной атакой эфирного атома кислорода диметилкарбоната по атому кремния кремнийорганического полимера.

Ключевые слова: диметилкарбонат, полидиметилсилоксан, механизм реакции, метод теории функиионала плотности, кластерное приближение

\section{REFERENCES}

1. Tertykh V.A., Belyakova L.A. Chemical Reactions Involving Silica Surface, Kyiv: Naukova Dumka, 1991, 260 p. (in Russian).

2. Myronyuk I.F., Kurta S.A., Gergel T.V. et al. The chemisorption of oligomeric polydimethylsiloxane on the surface of fumed silica, Chem. Phys. Solid State, 10 (2009) 157 (in Ukrainian).

3. Schimmel K.-H., Schulz J. Polysiloxane. 4. Zum Verhalten linearer Poly(dimethylsiloxane) in Diethylamin, Acta Polym., 38 (1987) 536.

4. Okamoto M., Miyazaki K., Kado A. et al. Deoligomerization of cyclooligosiloxanes with dimethyl carbonate over solid-base catalysts, Catal. Lett., 88 (2003) 115.

5. Okamoto M., Suzuki S., Suzuki E. Polysiloxane depolymerization with dimethyl carbonate using alkali metal halide catalysts, Appl. Catal. A-Gen., 261 (2004) 239.

6. Protsak I.S., Tertykh V.A., Goncharuk O.V. et al. Hydrophobization of the fumed silica surface with polydimethylsiloxanes in the presence of alkyl carbonates, Chemistry, Physics, and Technology of Surface, 5 (2014) 226 (in Ukrainian).
7. Protsak I.S., Bolbukh Yu.M., Kozakevych R.B., Tertykh V.A. Viscosimetric study of polydimethylsiloxane depolymerization under action of dimethyl carbonate, Chem. Industry, 117 (2013) 58 (in Ukrainian).

8. Arico F., Tundo P. Dimethyl carbonate as a modern green reagent and solvent. Uspekhi Khimii, 79 (2010) 532 (in Russian).

9. Tundo $P$. New developments in dimethyl carbonate chemistry, Pure Appl. Chem., 73 (2001) 1117.

10. Schmidt M.W., Baldridge K.K., Boatz J.A. et al. General atomic and molecular electronic structure system, J. Comput. Chem., 14 (1993) 1347.

11. Becke A.D. Density functional thermochemistry. III. The role of exact exchange, J. Chem. Phys., 98 (1993) 5648.

12. Lee C., Yang W., Parr R.G. Development of the Colle-Salvetti correlation-energy formula into a functional of the electron density, Phys. Rev. B-Condens. Matter, 37 (1988) 785.

13. Wales D.J., Berry R.S. Limitations of the Murrell-Laidler theorem, J. Chem. Soc. Faraday Trans., 88 (1992) 543.

14. Fukui $K$. The path of chemical reactions - the IRC approach, Acc. Chem. Res., 14 (1981) 363.

Received 31.07.2014, accepted 26.11.2014 